$\begin{array}{cc}\text { JBAT 7(1) (2018) } 41-47 & \begin{array}{c}\text { p-ISSN 2303 0623 } \\ \text { e-ISSN } 24072370\end{array} \\ \text { Jurnal Bahan Alam Terbarukan } \\ \text { Terakreditasi: SK No.: 36b/E/KPT/2016 } \\ \text { http://journal .unnes.ac.id/nju/index.php/jbat }\end{array}$

\title{
The Effect of Contact Time and Ozon Dose to Polutants Reduction in Hospital Wastewater
}

\author{
Prayitno, Hadi Saroso, Hardjono, Sri Rulianah
}

DOI 10.15294/jbat.v7i1.11401

Chemical Engineering Department, State Polytechnic of Malang

\begin{tabular}{|c|c|}
\hline Article Info & Abstract \\
\hline $\begin{array}{l}\text { Article history: } \\
\text { Received } \\
\quad \text { October } 2017 \\
\text { Accepted } \\
\quad \text { March } 2018 \\
\text { Published } \\
\quad \text { June 2018 } \\
\text { Keywords : } \\
\text { Contact time; } \\
\text { Countercurrent; } \\
\text { Dose; } \\
\text { Hospital } \\
\text { wastewater; } \\
\text { Ozone; } \\
\text { Packing }\end{array}$ & \multirow[t]{2}{*}{$\begin{array}{l}\text { In Indonesia, Hospital wastewater treatment generally use biological process followed by } \\
\text { chlorination process. Chlorination process has a negative impact on the aquatic environment } \\
\text { that is cause death of other microorganisms by the residual chlorine. On the other hand, } \\
\text { ozone is more effective than chlorine in killing microorganisms and other pollutants in } \\
\text { hospital wastewater. The objective of research is to determine the effect of contact time and } \\
\text { dose of ozone to reduction of pollutants (BOD, COD, free Ammonia and Phenol) in hospital } \\
\text { wastewater. The experiment was carried out using an ozone reactor containing 'packing', an } \\
\text { ozone generator as an ozone gas supplier. The experimental material is a hospital wastewater } \\
\text { containing BOD, COD, Phenol and Ammonia free. The experimental variables used were: } \\
\text { Contact time (1, 2, and } 3 \text { min), Dose of ozone (10, } 15 \text {, and } 20 \text { mg/ L). Experiments were } \\
\text { done by flowing hospital waste water at the top of the reactor ozone at certain rate and } \\
\text { simultaneously flowed ozone gas from an ozone generator in the bottom of the ozone reactor } \\
\text { so that it contacts the fluid in counter-current to the surface of the packing material (packing) } \\
\text { in an ozone reactor. By adjusting the flowrate of the wastewater and the height of the packing, } \\
\text { it can be determined the amount of contact time and ozone dose. Furthermore, by measuring } \\
\text { the amount of pollutant concentration on the influent and effluent of the ozone reactor, it can } \\
\text { be obtained the amount of removal in the pollutant concentration of the hospital wastewater. } \\
\text { The results showed that contact time and ozone dose influence the decrease of pollutant } \\
\text { concentration in hospital wastewater where contact time at } 3 \text { minutes and ozone dose } 20 \\
\text { mg/L and ozonation time } 15 \text { minutes can reduce of pollutants concentration as BOD ( } 97 \%) \text {, } \\
\text { COD ( } 98 \%) \text {, Ammonia free ( } 97 \%) \text {, and Phenol ( } 96 \%) \text {. }\end{array}$} \\
\hline & \\
\hline
\end{tabular}

*This is a revised and extended version of an article which had been presented at SNTK UNNES 2017, Semarang,

Indonesia, September 20 th 2017.

\section{INTRODUCTION}

Hospital wastewater contain infectious, pathogen, biodegradative and radioactive pollutant produced from various unit of service, such as: diagnosis room, surgical room, rontgen room, laboratories, pharmacies room, kitchen, and laundry (Mahvi et al., 2009). Several infectious pollutants from surgical and diagnosis room are: Salmonella typhi, Escherichia coli, Hepatitis B. Pathogen pollutant produced from pharmacy, patient treatment room, and laboratories such as Lead $(\mathrm{Pb})$, phenol, Mercury $(\mathrm{Hg})$. Meanwhile biodegradative pollutant is mostly produced from kitchen and cafeteria (Prayitno et al., 2013). Several hospital wastewater pollutant can cause pollution if it is not treated well (Mahvi et al., 2009; Mastorakis et al., 2010; Kragelund et al., 2017; Muthanna, 2008). To reduce the pollutant concentration of hospital wastewater, generally biological process and chlorination are used. However excess usage of chlorine lead to environmental problem such as food chain breakdown in water ecosystem as the impact of the excess chlorine (Ekhaise \& Omavwoya 2008; Tsai \& Lin 1999). 


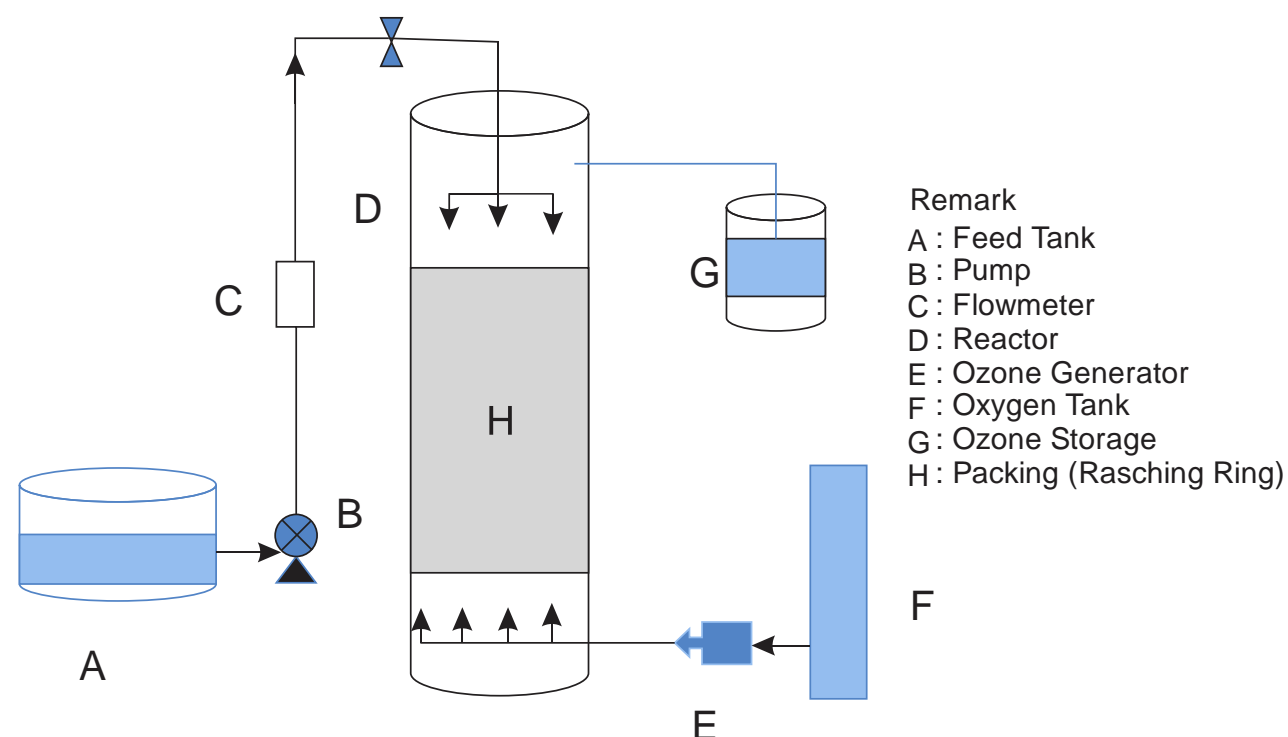

Figure 1. Sketch of experimental apparatus (Ozone Reactor)

In another side, in Indonesia the usage of ozon of hospital wastewater is not yet widely used. Meanwhile ozonization has several advantages, such as: able to oxidize heavy metals, 3100 as fast as chlorine, easily soluble in water, react fast, strong disinfectant which can kill numerous bacteria such as Escherichia coli, Salmonella enteriditis, Hepatitis A Virus and other various pathogen microorganism (Nagarkatti,1991; Eng, 2002). Through oxidation by ozone gas both directly or indirectly that it reaction between ozone or free radical with pollutant in water causes destruction of outer layer of microorganism cell wall (cell lysis) and kill it (Cheremisinoff, 2002; Fallis, 2013; Amir et al., 2015).

The ozonization process of hospital wastewater generally occur in contact reactor, in which the absorption and desorption mechanism occurred which further called mass transfer from gas (ozone) to liquid phase (waste water) and reversible process. The rate of mass transfer depends on: solubility, $\mathrm{pH}$, initial concentration, contact time, flow motion, and also the shape and type of packing (Fallis 2013; Eng 2002). Several type of contact reactor in ozonization process, such as: stripping column, packed column, tray column, plate column and spray column (Srikanth et al., 2013). In packed reactor there are several type of packing used in order to make mass trasfer occur efectively, such as: rasching rings, berl saddles, rasching ring, spiral rings, lessing rings, cross-partition rings (Fallis, 2013; Nagarkatti, 1991; Srikanth et al., 2013). Another more effective way to increase contact time is by increasing contacted surface area between gas phase and liquid phase by decreasing the size of ozone bubble dispersed in solution (Nagarkatti 1991). In another hand, phenol ozonization in wastewater using bubble column reactor can increase ozone mass transfer, phenol oxidation rate and solubility and ozone decomposition rate (Palit 2009). Therefore this research aims to find out the effect contact time and ozone dose to pollutant concentration reduction in hospital waterwaste in packed reactor with packing shaped rasching ring.

\section{RESEARCH METHODLOGY}

The research was conducted by using column reactor made of acrylic, in which the packed reactor with packing shaped rasching ring that made of glass. Ozone generator has function to produce ozone. Meanwhile the material used is wastewater from hospital as the product of biological process (effluent of wastewater installation plant) in one of the hospital in Malang. In which the hospital wastewater has characteristic as follow: Biological Oxygen Demand (BOD): 65 - 80 mg/L; Chemical Oxygen Demand (COD): 40 - 55 $\mathrm{mg} / \mathrm{L}$; Ammonia-free: $0.08-0.14 \mathrm{mg} / \mathrm{L}$; Phenol : $0.05-0.08 \mathrm{mg} / \mathrm{L}$. The variable used were contact time (1, 2, and 3 minute) and ozone dose $(10,15$, and $20 \mathrm{mg} / \mathrm{L})$. While fixed variables were $\mathrm{pH}(7-8)$, and type of packing (rasching ring).

Analytical methods was conducted using standard procedure of American Public Health Association (APHA), those are: Titration with Winkler bottle for BOD analysis, open reflux for 


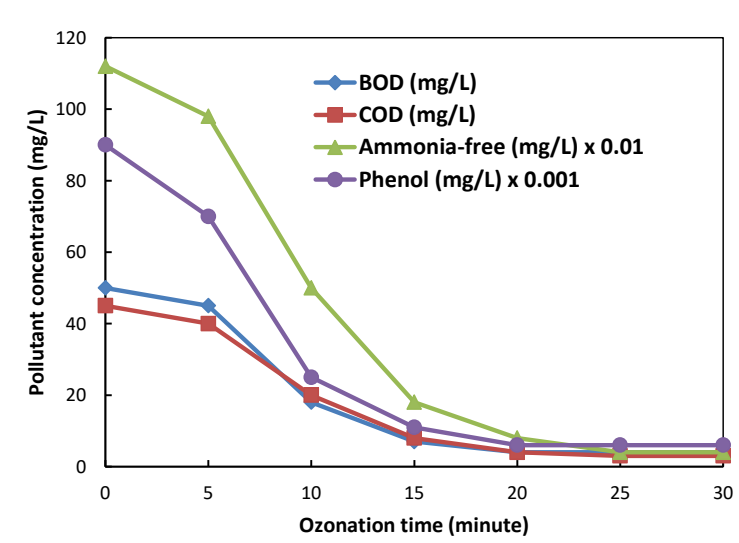

(a)

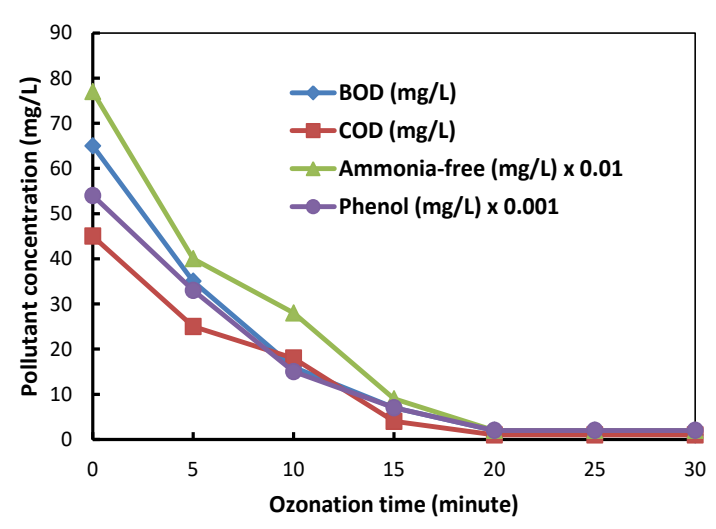

(b)

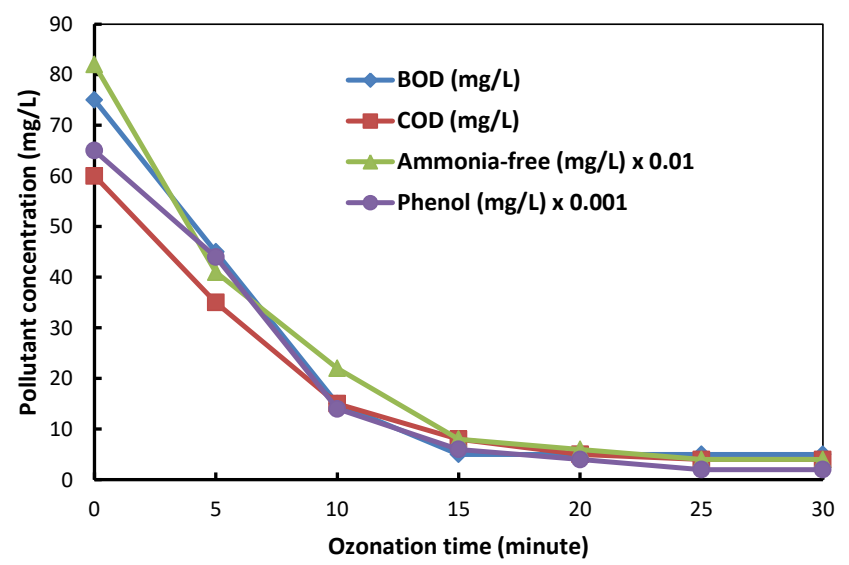

(c)

Figure 2. Pollutant concentration reduction in wastewater at various dose of ozone for contact time of 3 minutes (a) Ozone dose: $10 \mathrm{mg} / \mathrm{L}$; (b) Ozone dose: $15 \mathrm{mg} / \mathrm{L}$; (c) Ozone dose: $20 \mathrm{mg} / \mathrm{L}$

COD analysis, UV-Vis spectrophotometry for ammonia-free and phenol analysis (APHA/AWWA/WEF, 2012).

The experiment was conducted by filling the column (reactor) contain packing (rasching ring) for certain height so that it was obtained contact time as set (variable). Wastewater was collected and flow rate was set so that certain dose of ozone was obtained as desired (variable). Flow the ozone from ozone generator simultaneously (mass flowrate of ozone: $0.25 \mathrm{~g} / \mathrm{h}$ ) so that the contact of both liquid occurred on the surface of packing of rasching ring. The next wastewater in influent and effluent was collected and the pollutant concentration (BOD, COD, Ammonia free, phenol) were analyzed.

\section{RESULTS AND DISCUSSION}

\section{The Effect of Ozone Dose}

By making variation changes which is dose of ozone at $10 \mathrm{mg} / \mathrm{L}, 15 \mathrm{mg} / \mathrm{L}$, and $20 \mathrm{mg} / \mathrm{L}$ which is by way of flowrate of wastewater while flowrate of ozone fixed at $0.25 \mathrm{~g} / \mathrm{h}$ and keep $\mathrm{pH}$ of solution in the range: $7-8$, then the experimental data as shown in Figure 2.

Figure 2 shows that at a fixed contact time of $3 \mathrm{~min}$, the smaller the ozone dose used or the greater the wastewater flowrate the smaller the decrease in pollutant concentration in the wastewater. This was due to the smaller the dose of ozone, the more ozone contacts and reacts with the pollutants in the wastewater so that the reaction speed between ozone and pollutants will be greater and more of the pollutants are converted into other non-pollutant compounds (Cheremisinoff, 2002; Fallis, 2013; Eng, 2002). On the other hand, the rate of ozone reaction is affected by the dose, time, $\mathrm{pH}$, initial concentration of pollutants, solubility and temperature (Palit, 2009; Hoigné \& Bader 1983; Juhna \& Melin 2006).

Figure 2 shows that at a dose of $10 \mathrm{mg} / \mathrm{L}$, percentage of pollutants reacted was smaller than at ozone dose of $15 \mathrm{mg} / \mathrm{L}$. This is due to a dose of 10 


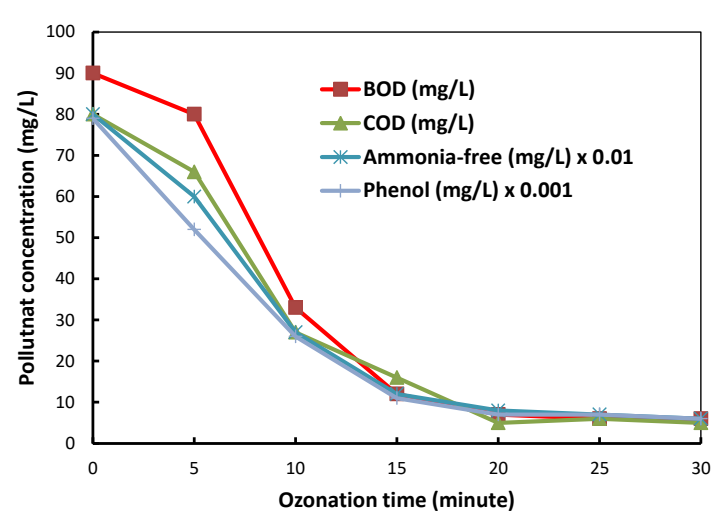

(a)

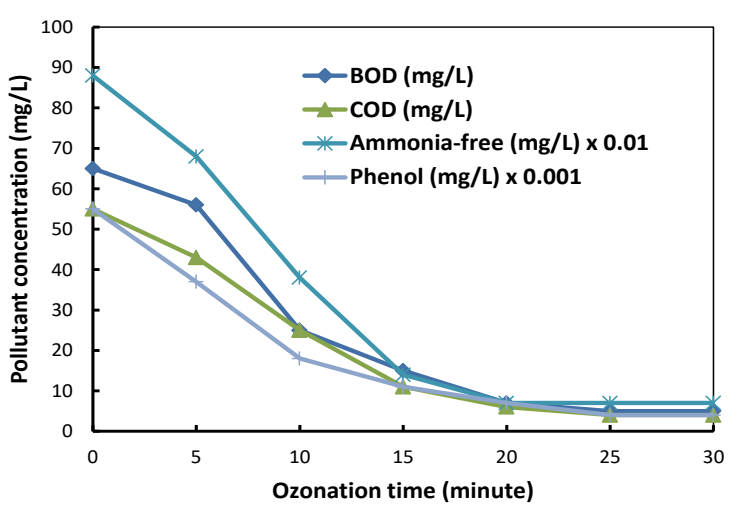

(b)

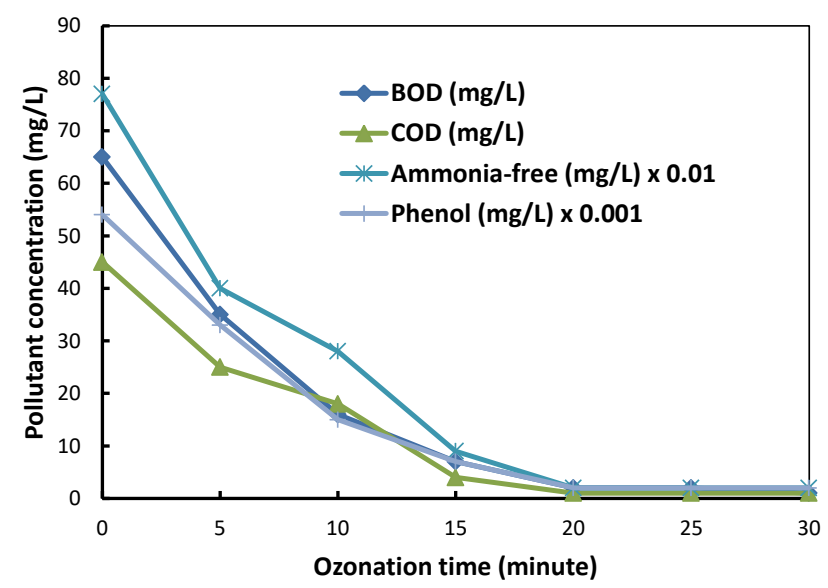

(c)

Figure 3. Pollutant concentration reduction in wastewater at various contact time for ozone dose of 15 mg/L (a) Contact time: 1 minute; (b) Contact time: 2 minute; (c). Contact time: 3 minute

$\mathrm{mg} / \mathrm{L}$ in floading (the space in reactor is fully charged by liquid), wherein the liquid (wastewater) entering the column (reactor) and retained by very large packing so that the ozone gas transfer into the liquid (waste water) was reduced so that the ozonization reaction was less effective. While at a dose of $20 \mathrm{mg} / \mathrm{L}$ the process of mass transfer of ozone gas to liquid is also less effective because liquid still not fully fill space hollow between the packing (rasching rings) so that the ozonization reaction has not been perfect.

A dose of $15 \mathrm{mg} / \mathrm{L}$ was the optimal dose for ozonization of hospital wastewater, wherein an contact time of 3 minute can remove the pollutants by BOD (97\%), COD (98\%), ammonia free (97\%), and Phenol (96\%) respective. On the other hand, Fixed bed bubble column that batch operate was effective in color removal in textile industry wastewater, with contact time of 30 minutes can decrease color by $98 \%$ (Palit 2009). The Ozone has a high solution in water and reacts to form a hydroxyl group (OH-) which acts as a strong oxidizer in the first 10 minutes. Besides ozone also as a disinfectant that was very effective in killing bacteria (coli faeces) and oxidize heavy metals (Dsatan \& Masood, 2015; Eng, 2002; Sánchez-Polo et al., 2006).

\section{The Effect of Contact Time}

By making changes of contact time for 1 minute, 2 minute, and 3 minute so that the data obtained from the experimental results as Figure 3.

Figure 3 shows that at a fixed $\mathrm{pH}$ of 7.5 and a fixed dose of ozone of $15 \mathrm{mg} / \mathrm{L}$, in average decrease in very high pollutant concentrations at contact time of 3 minutes and 1 minute while at contact time of 2 minute accur the decrease of pollutant was relatively small, where the decrease in pollutant concentration was marked by the steepness of the curve.

The ozone contact time is the time required by ozone to contact the wastewater, where the contact time is closely related to the height and shape of the columns (reactor). The higher the column of content and the more surface area of of pack the longer the contact time between the ozone 
Table 1. The percentage reduction of pollutant concentration in wastewater with ozonization time of 20 minutes.

\begin{tabular}{|c|c|c|c|c|c|c|c|c|c|c|c|c|}
\hline \multirow{2}{*}{$\begin{array}{l}\text { Ozone } \\
\text { Dose } \\
(\mathrm{mg} / \mathrm{L})\end{array}$} & \multicolumn{4}{|c|}{ Contact Time : 1 minute } & \multicolumn{4}{|c|}{ Contact Time: 2 minute } & \multicolumn{4}{|c|}{ Contact Time: 3 minute } \\
\hline & BOD & COD & $\begin{array}{l}\text { Ammonia } \\
\text { Free }\end{array}$ & Phenol & BOD & $\mathrm{COD}$ & $\begin{array}{l}\text { Ammonia } \\
\text { Free }\end{array}$ & Phenol & BOD & COD & $\begin{array}{l}\text { Ammonia } \\
\text { Free }\end{array}$ & Phenol \\
\hline 10 & 92 & 93 & 91 & 87 & 88 & 94 & 92 & 91 & 92 & 91 & 93 & 93 \\
\hline 15 & 92 & 94 & 90 & 91 & 89 & 89 & 92 & 87 & 97 & 98 & 97 & 96 \\
\hline 20 & 94 & 94 & 92 & 93 & 96 & 9 & 94 & 96 & 93 & 92 & 93 & 94 \\
\hline
\end{tabular}

gas and the wastewater so that an easier ozonization reaction between the ozone gas and the pollutants in the wastewater. In this experiment for contact time of 2 minutes, The column still do not allow effective ozone reactions to occur over contact time of 1 minute or 3 minute resulting in a decrease in small realistic ozone concentrations. Meanwhile the time of ozonization states how long the ozonization process takes place, where the longer the ozonization time the higher the occurrence of ozonization reaction so that the greater the proportion of pollutant decrease in wastewater. Figure 3 shows that with ozonization time of 20 minute, steady state condition was achieved indicated by a decrease in the concentration of stable pollutants.

In the ozonization process the $\mathrm{pH}$ affect the decrease of pollutant concentration, where at $\mathrm{pH}$ of 8.3 accor the decreases the concentration of COD $(75.5 \%)$, TOC $(59.1 \%)$, color $(77 \%)$, and phenol $(52.3 \%)$ respectively. Similarly, the $\mathrm{pH}$ change from 8.3 to 10 , within ozonization time of 60 minutes can reduce the phenol concentration by $48.5 \%$ to $74 \%$ (Assalin et al., 2009). Additionally, the increased contact time of ozonization will increase color and COD removal, which at dose of $125 \mathrm{mg} / \mathrm{L}$ and ozonization time for 25 minutes can decrease the color concentration (51.3\%) and COD (67\%) (Yasar et al., 2007).

In the process of ozonization using a packed column shaped rasching ring which hydrodynamic effect greatly affect the movement of ozone molecules, which in the packing shaped rasching ring will increase the outer surface of the contact between the ozone gas bubbles with the liquid phase (wastewater) that will increase contact time and reaction between ozone gas and wastewater. Some types of reactors used to increase mass transfer include: fixed packed bed, rotating packed bed, bubble column and bubble diffuser reactor. The percentage of organic matter taken was higher in the bubble column than the bubble of a diffuser due to the dissolved ozone concentration in the bubble column was higher than the bubble of the diffuser (Palit, 2009; Eng, 2002).

Besides, there was effect of psycochemist include decomposition of ozone, temperature, pressure and chemical composition of liquid (wastewater) (Ko et al., 2011). Nevertheless in this study it more emphasis on hydrodynamic effect, where the packed reactor contains rasching ring which has wide area a large surface makes the movement of molecules in the fluid be smaller and increases the effective contact with the ozone gas so that the fluid flow forms a thin layer which can increase the mass transfer of ozone into the fluid (Ko et al., 2011). Furthermore, the increase of contact time will increase the conversion of pollutants in waste water by ozone. The increase in ozonization time will increase color and COD removal whereas at dose of $125 \mathrm{mg}$ and ozonization time of 25 minutes can decrease the color concentration by $51.3 \%$ and COD $67 \%$ (Yasar et al. 2007).

Oxidation of ozone to organic materials (BOD, COD, and ammonia-free) was higher than phenol. This is because ozone has high solubility in water and reacts by forming a hydroxyl group $(\mathrm{OH}-$ ) which acts as a strong oxidizer and readily reacts with straight-chain organic materials compared to phenol having a circular chain (Forero et al., 2001; Nagarkatti, 1991).

Furthermore, from experimental data for various dose of ozone and contact time of ozone with ozonization time of 20 minutes, the occurrence time of steady state condition is obtained by the data of percentage of the decrease of pollutant in waste water as Table 1.

The data on Table 1 shows that at contact time of 3 minutes and ozone dose of $15 \mathrm{mg} / \mathrm{L}$, the highest concentration reduction of pollutants was BOD (97\%), COD (98\%), ammonia-free (97\%) and Phenol (96\%). Therefore the packed reactor with pack shaped rasching ring and countercurrent flow has a good ability to take pollutants of hospital wastewater (BOD, COD, free ammonia, and phenol). 


\section{CONCLUSION}

Contact time and ozone dose affect pollutant concentration reduction in hospital wastewater, in which at contact time of 3 minute and ozone dose of $15 \mathrm{mg} / \mathrm{L}$ can reduce BOD, COD, ammonia-free, and phenol as $97 \%, 98 \%$, $97 \%$, dan $96 \%$ respectively.

\section{ACKNOWLEDGEMENTS}

The authors would like to acknowledge the financial support provided by Research, Technology and Higher Education Ministry of Indonesia. They would also like to thank the Research Affairs at State Polytechnic of Malang for their support.

\section{REFERENCES}

APHA/AWWA/WEF. 2012. Standard Methods for the Examination of Water and Wastewater. Standard Methods. p. 541.

Assalin, M. R., Almeida, E. D. S., Duran, N. 2009. Combined System of Activated Sludge and Ozonation for the Treatment of Kraft $E_{1}$ Effluent. International Journal of Environmental Research and Public Health. 6 (3): 1145-54.

Cheremisinoff, N. P. 2002. Handbook of Water and Wastewater Treatment Technologies. Handbook of Water and Wastewater Treatment Technologies. ButterworthHeinemann.

Dastan, S. A. M., Masoodi, H. 2015. The Use of Ozone in Hospital Wastewater Treatment. Cumhuriyet University Faculty of Science Science Journal. 36(6):1358-1364.

Ekhaise, F. O., Omavwoya, B. P. 2008. Influence of Hospital Wastewater Discharged from University of Benin Teaching Hospital (UBTH), Benin City on Its Receiving Environment. American-Eurasian Journal of Agricultural \& Environmental Sciences. 4 (4): 484-88.

Eng, A. S. P. 2002. Ozone Technology and Applications. New Foundland Water Treatment Technical Conference. Presented on March 2002.

Fallis, A. G. 2013. Ozone in Wastewater Treatment. Journal of Chemical
Information and Modeling. 53 (9): 168999.

Forero, J. E., Duque, J. J., Rios, F., Díaz, J. 2001. Ozone for Phenol Treatment in Industrial Wastewater. CT and F - Ciencia, Tecnologia Y Futuro. 2 (2): 17-26.

Hoigné, J., Bader, H. 1983. Rate Constants of Reactions of Ozone with Organic and Inorganic Compounds in Water-I: NonDissociating Organic Compounds. Water Research. 17(2):173-183.

Juhna, T., Melin, E. 2006. Ozonation and Biofiltration In Water Treatment Operational Status and Optimization Issues. Techneau. D.5.3.1.B: 80.

Ko, C. H., Guan, C. Y., Lu, P. J., Chern, J. M. 2011. Ozonation of Guaiacol Solution in a Rotating Packed Bed. Chemical Engineering Journal. 171 (3):1045-1052.

Kragelund, C., Ooi, G. T. H., Tang, K., Christensen, A. T., Bester, K., Andersen, H. R. 2017. Efficient Pharmaceutical Removal from (Hospital) Wastewater by Staged-Moving Bed Biofilm Reactors (MBBRs) Followed by Ozonation. 11 $1^{\text {th }}$ Annual Meeting of DWF. Presented on $30^{\text {th }}$ January.

Mahvi, A., Rajabizadeh, A., Fatehizadeh, A., Yousefi, N., Hosseini, H., Ahmadian, M. 2009. Survey Wastewater Treatment Condition and Effluent Quality of Kerman Province Hospitals. Environmental Health. 7 (12): 1521-25.

Mastorakis, N., Bulucea, C., Opréa, T., Dondon, P. 2010. Environmental and Health Risks Associated with Biomedical Waste Management. Proceedings DEEE. 7 (8): 287-94.

Muthanna, T. M. 2008. The Impact of Hospital Sewage Discharge on the Assessment of Environmental Risk Posed by Priority Pharmaceuticals: Hydrodynamic Modelling and Measurements. 2006: 1-10.

Nagarkatti, M. G. 1991. Ozone in Water Treatment: Application and Engineering. Journal of Environment Quality. 20: 881.

Palit, S. 2009. Ozonation of Direct Red-23 Dye in a Fixed Bed Batch Bubble Column Reactor. Indian Journal of Science and Technology 2 (10): $14-16$.

Prayitno, P., Kusuma, Z., Yanuwiadi, B., Laksmono, R. W. 2013. Study of Hospital 
Wastewater Characteristic in Malang City. Research Inventy: International Journal Of Engineering And Science. 2 (2): 13-16.

Sánchez-Polo, M., Salhi, E., Rivera-Utrilla, J., Gunten, U. V. 2006. Combination of Ozone with Activated Carbon as an Alternative to Conventional Advanced Oxidation Processes. Ozone: Science and Engineering 28 (4): 237-45.

Srikanth, A., Sathish, M., Harsha, A. V. S. 2013. Application of Ozone in the Treatment of
Periodontal Disease. Journal of Pharmacy BioAllied Science. 5 (1): 89-94.

Tsai, C. T., Lin, S. T. 1999. Disinfection of Hospital Waste Sludge Using Hypochlorite and Chlorine Dioxide. Journal of Applied Microbiology. 86 (5): 827-33.

Yasar, A., Ahmad, N., Chaudhry, M. N., Rehman, M. S.U., Khan, A. A. A.. 2007. Ozone for Color and COD Removal of Raw and Anaerobically Biotreated Combined Industrial Wastewater. Polish Journal of Environmental Studies. 16 (2): 289-94. 